\title{
Are Islamic Equity Indices More Efficient Than Their Conventional Counterparts? Evidence From Major Global Index Families
}

\author{
Abdelbari El Khamlichi, LERSEM, ENCG, Chouaib Doukkali University, Morocco \\ Kabir Sarkar, Taylor's Business School, Taylor's University, Malaysia \\ Mohamed Arouri, EDHEC Business School, France \\ Frédéric Teulon, IPAG Business School, France
}

\begin{abstract}
Despite the increasing attention to ethical investments, the empirical studies on Islamic indices are scarce. Our article aims to contribute to the empirical literature by exploring the efficiency of these indices and their potential for diversification in comparison with the conventional benchmarks. We explore the existence of diversification opportunities by studying whether indices are cointegrated or not. Then, the weak-form efficiency level is analyzed by testing the random walk hypothesis using variance ratio tests. Our sample includes Islamic and mainstream indices of four indices families; among them, two Shariah-compliant indices which have not been studied before in the academic literature Our results show that Islamic indices have the same level of (in)efficiency as conventional ones, the indices of MSCI and FTSE families are the less inefficient. In terms of cointegration analysis, Islamic indices of Dow Jones and $S \& P$ have no cointegrating relations with their respective benchmarks, which suggests the existence of long-run diversification opportunities.
\end{abstract}

Keywords: Islamic Finance; Indices; Diversification; Cointegration; Efficiency; Variance Ratios

\section{INTRODUCTION}

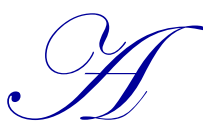

fter some modest attempts to establish Islamic financial institutions (IFI's) during the early sixties, the real beginning of the Islamic financial industry took place during the mid-seventies. Fundamentally, different from the conventional financial model, Islamic finance has its religious identity and is based on a set of principles referred to as Shariah (Islamic law). The most important among them are the profit and loss sharing, risk sharing, prohibition of interest, asset-backing principle, and prohibition of excessive uncertainty. In addition to the principles, Islamic financial institutions must avoid the business with some nonethical sectors such as liquor, pornography, pork, etc. By applying these principles, the Islamic financial system was established to take into consideration, besides religious aspects, moral, ethical, and social dimensions. It was also deemed to be more stable than the conventional system especially during crisis periods (Arouri et al., 2013). In recent years, Islamic banking and finance has been recognized as a rapidly growing part of the financial sector. While the advocates of the Islamic system promote its ability to promote equity and justice (Jobst, 2007), some papers documented the divergences between the ideals and the practices of some Islamic institutions (Khan, 2010).

Due to the prohibition of interest, the need for equity markets is higher in Islamic finance (Iqbal, 2002). Hence, Islamic financial institutions as well as investors seeking for profit earned from their portfolio through ownership of assets are involved in the stock markets. All stocks in the stock markets may not represent ownership in ethical assets and businesses, which inspires Muslim scholars and economists to establish Islamic equity markets so that investors could invest in ethical financial instruments to earn profit in an ethical way. Meanwhile, a number 
of recent innovations in terms of product design and risk management have taken place with the surge of the Islamic capital market. One of the aspects of these innovations was the launching of Shariah-compliant indices which are considered a part of faith-based or morally responsible investments (Ghoul \& Karam, 2007). El-Gamal (2006) asserted that these indices can be best described as "avoiding explicit and major violations of legal prohibition." Their principle is similar to that of social indices in terms of screening, both of them have supervisory boards which provide advice on eligibility of companies, but the main difference between them is that the referent is religious for Islamic indices and compliance is guaranteed by Shariah boards. In order to meet the growing demand for ethical products and services, Shariah-compliant indices were introduced by globally reliable indices' providers including Dow Jones, FTSE, Standard \& Poor's, and Morgan Stanley.

Chronologically, Islamic indices were launched for the first time in the late nineties, the beginning was in April 1998 with the index DMI 150 (Dar al Mal al-Islami) launched jointly by two private banks (Faisal Finance and Bank Vontobel) in order to track the performance of the 150 largest global publicly traded companies. Another index was created in November of the same year, it was SAMI (Socially Aware Muslim Index) which measured the performance of 500 Shariah compliant companies. After this beginning, several financial markets had launched their own Islamic indices as a new alternative for investors seeking investment opportunities without compromising their beliefs. Hence, Dow Jones created the Dow Jones Islamic Market Index (DJIMI) on February 1999 and FTSE Group launched Global Islamic Index Series (GIIS) at the London Stock Exchange on October 1999. The index provider Standard and Poor's created the Global Benchmark Shariah indices on December 2006 and MSCI Barra launched its global family of Islamic indices in March 2007. In February 2011, Stoxx limited introduced the first set of Shariah compliant indices for Europe and Euro zone, these indices measure the performance of Shariah compliant companies selected from the universe of Stoxx Europe 600 index (see Appendix 1 for more details). In addition to the previous indices which had an internationally geographical coverage, some financial markets such as Malaysia, India, Pakistan, Saudi Arabia, Taiwan, Bahrain, Turkey, and Egypt have introduced their own Islamic indices with a local focus.

All Islamic indices follow a common stock selection process which is termed stock screening. While basic prohibitions and Shariah rules are strictly maintained in the screening process, different indices may differ in some screening criteria. The benchmarks from which Islamic indices are selected are well-recognized conventional indices. In practice, Shariah scholars and regulators have developed qualitative and quantitative screens to filter out the stocks and to assess their compliancy to Islamic principles. The independent Shariah boards define two-step screening process regarding the activity sector of firms and their financial ratios (Appendix 2).

The first step of screening is based on the line of companies business. The idea of the negative screening is to exclude companies operating in specific areas based on their activity sector. In addition to two classical classifications, namely the General Industry Classification Standard (GICS) and the Industry Classification Benchmark (ICB), the Standard Industrial Classification (SIC) system offers the advantage to assign multiple codes based on the businesses the company is operating in (Derigs \& Marzban, 2009). The divergence between Shariah scholars occurs when the company's main business is lawful but fraught with some prohibited transactions. The issue here is the extent to which the unlawful activity is a primary activity of the company (Yaquby, 2000; ElGamal, 2006).

The second step of screening concerns quantitative screens based on financial ratios. The idea of these ratios have germinated when pioneering Islamic institutions asked for allowance to include in their portfolios stocks of companies with small or negligible amount of interest and unlawful income (El-Gamal, 2006). The authorized levels are not the same for all Shariah-boards; this can lead to significantly different asset universes according to the used methodology (Derigs \& Marzban, 2008). That's why this practice of screening could not gain scholar's unanimous support and the debate over its permissibility is not over yet.

In terms of academic researches, Islamic indices have not received a high level of scrutiny. This situation can be explained by the short histories of Islamic indices and by some methodological difficulties due to differences in size and industry-weighting (Fowler \& Hope, 2007). 
Using Engle and Granger's (1987) cointegration technique, this study finds the absence of cointegration among two index families (Dow Jones and Standard \& Poor's), which use market-capitalization screening requirements. This recommends that diversification opportunities exist for the mentioned indices. For the two remaining pairs of indices (FTSE and MSCI), which use asset-based screening requirements, the study finds that they are cointegrated and thus absence of diversification benefits. As random walk is linked to the efficient market hypothesis (Malkiel, 2003), variance ratio tests are used to assess the efficiency of indices. Our findings show that both Islamic and conventional indices have the same tendencies and therefore the same level of (in)efficiency. The variance ratio tests reveal that the global indices of FTSE and MSCI are the less inefficient.

The remainder of this paper is organized as follows. Section 2 underlines the motivation of our study. Section 3 reports the literature review. Section 4 describes the data. Section 5 presents the econometric modeling. Section 6 discusses the results of the study. The study wraps up with the conclusion in Section 7.

\section{MOTIVATION OF THE STUDY}

Our literature review shows that the majority of studies focused on a single index, which may not portray the real picture of Islamic stock markets around the world. To overcome this shortage our article contributes to the current literature by studying a couple of Islamic and conventional indices. The motivation of our study is twofold. First, to provide evidence on whether Islamic indices offer an opportunity of diversification, and second, to investigate whether Islamic indices are efficient or not as compared to their mainstream counterparts. On the one hand, we test diversification opportunities using cointegration tests. Hence, the presence of cointegrating variables shows a long-term relationship between Islamic and conventional indices and the lack of diversification opportunities. On the other hand, our article aims to assess the difference in terms of efficiency among Islamic indices and their benchmarks. For this reason, we test the random walk hypothesis using variance ratios analysis based on temporal dependence in price series.

\section{LITERATURE REVIEW}

The real beginning of modern Islamic economic has taken place in the mid seventies with the establishment of financial institutions such as the Development Islamic Bank and Dubai Islamic Bank. Since the early eighties, the model of Shariah-compliant economics has been criticized by some researchers (Kuran, 1983). But in the nineties, Islamic banks have grown significantly and gained interest in both Muslim and non-Muslim countries (Ebrahim \& Safadi, 1995).

Islamic capital market including Islamic equity indices is the recently developed interest area of the researchers. A number of studies have been conducted in this area, which mostly followed qualitative approach focused on Islamic financial principles and framework of Islamic capital markets. Hence, the first qualitative studies analyse the Islamic financial principles within the market framework. For example, Elgari (1993) and Alhabshi (1994) discussed the feasibility of an Islamic financial market and its particularities in terms of practices and regulation. Other researchers analyzed the compliancy of the main activities in the conventional capital market in the light of Islamic principles (Anwar, 1995), as well as the various Shariah-compliant instruments to evolve the Islamic financial market (Ahmad, 1997). The Malaysian market was one of the most important financial markets which developed Islamic tools in order to serve investors seeking for opportunities without compromising their beliefs (Annuar et al., 1997). What's more, Naughton and Naughton (2000) analyzed Islamic stock market at its early stage and its particularities in terms of practices and regulation.

Among the earlier quantitative studies on the Islamic equity indices, a few studies have focused on the Dow Jones Market Index (DJIMI) such as Atta (2000) who used back-tested data in her analysis. The other studies using the same index family include Hassan (2001), Tilva and Tuli (2002) and Hakim and Rashidian (2002, 2004). Majority of these studies followed the same methodologies of comparing the performance of DJIMI to other benchmarks but the choices are quite different from one research to another in terms of performance measures and benchmarks. Another group of studies by Hussein (2004), Miglietta and Forte (2007), Girard and Hassan (2008), as well as Binmahfouz and Hassan (2012) analyzed the performance of the FTSE Islamic indices. 
As for Malaysian Islamic stock market, the Kuala Lampur Shariah Index was studied by a number of researchers. Prominent studies by Ahmad and Ibrahim (2002), Albaity and Ahmad (2008), and Yusof and Majid (2007) have addressed various issues of DJIMI, FTSE, and Malaysian Islamic indices. Some particular studies focused on other markets such as the Pakistani stock market (Nishat, 2004) or that of the Saudi Arabia (Dabbeeru, 2006).

Only a few studies have addressed the issues of the existence of diversification opportunities. Hakim and Rashidian (2004) found that despite investment restrictions, the exclusion of industries from the Islamic index of Dow Jones did not seem to have hurt its diversification, but may have contributed to reduce its market risk. Guyot (2011) analyzed the same index family and found the absence of cointegration over the long term between nine pairs of Islamic and conventional indices and therefore, diversification benefits for international investors. Girard and Hassan (2008) used a multivariate cointegration analysis and found that Islamic and conventional groups of FTSE are integrated. They also asserted that both types of indices have similar reward to risk and diversification benefits. Since the authors found no significant differences between Islamic and conventional indices of FTSE, they suggested to use them as asset classes to have more diversification benefits. Kok et al. (2009), who found the similar conclusion, exhibited the existence of diversification opportunities by grouping FTSE Global Islamic with conventional and socially responsible indices.

While the promotion of efficiency and ethics in stock markets are the main goals of policy makers and regulators, El-Gamal (2002) documented some efficiency losses induced by trading in risk and uncertainty. The efficiency of Islamic indices was a subject of some empirical studies. Indeed, Obaidullah (2001) supported the idea that, in spite of ethical concerns, an Islamic stock market is not less efficient than a conventional one. Hassan (2001) found that Dow Jones Islamic indices are more efficient than their conventional counterparts. Girard and Hassan (2008) showed that Islamic indices and conventional indices of FTSE have the same tendencies and offer the same level of efficiency. At the same time, Guyot (2011) showed that Shariah selection restrictions of Dow Jones Islamic indices did not affect their efficiency.

Following Guyot (2011), this study recommends to extend the research by considering some issues of less explored indices. The study suggests to apply the cointegration technique to other index families in addition to FTSE and Dow Jones. For each family, the lack (presence) of cointegration between indices would mean that long term diversification opportunities (don't) exist. This paper conducts a global study focused on four pairs of global Islamic and conventional indices, whereby, contributes to improve the comprehension of the investment characteristics of Islamic indices. Besides, this study analyzed whether the indices actually offer diversification opportunities as claimed by the advocates of ethical indices and whether their efficiency level is different from that of conventional indices.

\section{DATA}

This study used daily prices of Dow Jones, Financial Times, Standard \& Poor, and Morgan Stanley's Islamic and conventional indices starting from their available date to March 09, 2011. All data are collected from three data bases: Factset, Datastream, and Reuters 3000 Xtra v.5.1. Table 1 presents the Islamic and conventional pairs of indices included in our study.

Table 1: Islamic Indices and Their Conventional Benchmarks

\begin{tabular}{|l|c|c|c|c|}
\hline \multicolumn{1}{|c|}{ Index Family } & Islamic Indices & Conventional Benchmarks & Data From & Observations \\
\hline Dow Jones & $\begin{array}{c}\text { Dow Jones Islamic Market } \\
\text { (DJMKT) }\end{array}$ & Dow Jones Global (W1DOW) & $31 / 12 / 1998$ & 3167 \\
\hline Financial Times & FTSE Shariah all World (FSAWRD) & FTSE All Shares (FAWRLD) & $29 / 10 / 2007$ & 868 \\
\hline Standard \& Poor's & S\&P500 Shariah (SP500S) & S\&P500 (SP500) & $03 / 01 / 2007$ & 1054 \\
\hline Morgan Stanley & MSCI AC World IS (MSACWS) & MSCI World (MSWRLD) & $01 / 01 / 2008$ & 802 \\
\hline
\end{tabular}

\section{ECONOMETRIC MODELLING}

This study employs the Engle and Granger (1987) approach to examine the cointegration among the Islamic equity indices with a view to check the long-run theoretical relationship. In order to examine the efficiency 
of Islamic indices as compared to their counterparts, our study employs Lo and Mackinlay (1988) tests of random walk hypothesis based on variance ratios.

\subsection{Cointegration and Other Related Tests}

As sub-indices, Islamic indices might be highly correlated with their benchmarks. This high correlation does not imply high cointegration. Indeed, cointegrated indices might have high (or low) correlation at time. This is due to some extreme move of certain stocks that are excluded from the Islamic indices.

In order to investigate whether indices are cointegrated or not, we use a unit-root test of Dickey-Fuller $(\mathrm{ADF})^{*}$ as a starting point for the cointegration analysis following Engle and Granger (1987). The lag length for the time series analysis is determined by choosing the lag length given by the minimum Akaike Information Criteria and Schwarz Information Criteria. The Augmented Dickey-Fuller (ADF) $(1979,1981)$ test involves the estimation of the following general specification:

$$
\Delta x_{t}=\alpha_{0}+\alpha_{1} T+\beta x_{t-1}+\sum_{j=1}^{P} \delta_{1} \Delta x_{t-1}+\varepsilon_{t}
$$

where, $\mathrm{x}$ stands for the variable whose stationarity should be checked and $\varepsilon$ is the residual term. $\Delta$ represents the difference operator, $\alpha, \beta$, and $\delta$ are the three coefficients to be estimated. The critical values for the Dickey-Fuller test depend on whether the regression contains an intercept term or a time trend.

After assessing that the two variables $\left(\mathrm{x}_{\mathrm{t}}\right.$ and $\left.\mathrm{y}_{\mathrm{t}}\right)$ have the same order of integration $I(d)$, the cointegration approach consists of a two-step procedure for cointegration analysis:

1. Estimate the long-run equilibrium equation:

$y_{t}=\delta_{0}+\delta_{1} x_{t}+u_{t}$

The residual is given by:

$\hat{\mathrm{u}}_{\mathrm{t}}=\mathrm{y}_{\mathrm{t}}-\hat{\delta}_{0}-\hat{\delta}_{1} \mathrm{x}_{\mathrm{t}}$

A test of potentially cointegrating relation is a test of whether the residual is stationary or not. Engle and Granger (1987) compared various unit-root tests and recommended the ADF test.

2. Estimate the Error Correction Model (ECM):

$$
\Delta \mathrm{y}_{\mathrm{t}}=\phi_{0}+\sum_{\mathrm{j}=1} \phi_{\mathrm{j}} \Delta \mathrm{y}_{\mathrm{t}-\mathrm{j}}+\sum_{\mathrm{h}=0} \theta_{\mathrm{h}} \Delta \mathrm{x}_{\mathrm{t}-\mathrm{h}}+\alpha \hat{\mathrm{u}}_{\mathrm{t}-\mathrm{t}}+\varepsilon_{\mathrm{t}}
$$

The Error Correction Model (ECM) is applied to determine the endogeneity/exogeneity of the variables. The error correction term (ECT) stands for the long term relations among the variables. At least one of the ECT terms should be significant for the validity of the cointegrating relationship among the variables in the long term. If the error correction term is insignificant, the corresponding dependent variable is 'exogenous.' On the contrary, if the error correction term is significant, the corresponding dependent variable is 'endogenous.' The ECM implies that changes in the dependent variable are a function of the level of disequilibrium in the cointegrating relationship; i.e., 
the departure from the long-run equilibrium as well as changes in other explanatory variables. The reaction of $\mathrm{y}_{\mathrm{t}}$ to the disequilibrium error is captured by the adjustment coefficient $\alpha$ which must be negative and significant. The presence of cointegration indicates that there exists a theoretical relationship among the variables and they tend to move together in the long-run in spite of short-run deviation from each other.

\subsection{Efficiency Tests}

To investigate the market quality, we conduct a comparative analysis of Islamic and conventional indices. The question of whether the market is efficient has long been the subject of considerable interest among researchers since the pioneering work of Fama (1965). In order to test the efficiency, random walk tests are widely used. Hence, Malkiel (2003) outlined the relationship between random walk and the efficient market hypothesis. He argues that if prices follow random walk, all subsequent price changes are random departures from previous prices. In this case, stock prices reflect immediately all available information.

Lo and Mackinlay (1988) provide tests of random walk hypothesis based on variance ratios. This approach has been the most widely used econometric tool to test random walk hypothesis and remains superior to many other tests (Hoque et al., 2007).

Unit-root tests are not sufficient to test random walk hypothesis as documented by Gilmore and McManus (2003) as well as Guidi and Gupta (2011). Variance ratio tests are particularly useful for examining the behavior of stock prices even if returns are not normally distributed (Smith \& Ryoo, 2003). Hence, Lo and Mackinlay provide tests under the alternative assumption of homoscedastic and heteroscedastic disturbances. The latter is a heteroscedasticity-robust test statistic and remains sensitive to correlated changes in stock prices, this is what makes these tests and their extensions (Wright, 2000) particularly interesting.

The idea behind variance ratios is that under a random walk, the variance increases linearly in the observation interval. Indeed, if a stock's returns follow a random walk, the variance of k-period return is $\mathrm{k}$ times the variance of one period return. The variance ratio defined as the ratio of $1 / \mathrm{k}$ times the variance of the k-period return to the variance of the one-period return is given by:

$$
R V_{k}=\frac{\operatorname{Var}\left(x_{t}+x_{t-1}+\ldots+x_{t-k+1}\right)}{\operatorname{Var}\left(x_{t}\right)}=\frac{\delta^{2}(k)}{\delta^{2}(1)}
$$

Under the null hypothesis of random walk, meaning efficiency, the variance ratio should be equal to 1 for all values of $\mathrm{k}$.

$$
\begin{array}{lll}
\mathbf{H}_{0}: & \mathrm{RV}_{\mathrm{k}}=1 & \text { for } \mathrm{k}=1,2, \ldots, \mathrm{n} \\
\mathbf{H}_{1}: & \mathrm{RV}_{\mathrm{k}} \neq 1 & \text { for any } \mathrm{k}=1,2, \ldots, \mathrm{n}
\end{array}
$$

As suggested by Lo and Mackinlay (1988), we test the null hypothesis of random walk $\left(\mathrm{H}_{0}: \mathrm{RV}_{\mathrm{k}}=1\right)$ using test statistics assuming homoscedastiy $\mathrm{Z}(\mathrm{k})$ and heteroscedasticity-robust $\mathrm{Z} *(\mathrm{k})$. When the random walk hypothesis is rejected and $R V_{k}>1$, returns are said to be serially correlated.

\section{RESULTS AND INTERPRETATION}

\subsection{Cointegration}

ADF unit-root test suggests that Islamic and conventional indices are stationary at first difference, which implies that the indices are integrated of order one, I(1). Table 2 depicts the unit-root and cointegration test results. All the Islamic index series have the same order of integration, so we test the presence of cointegration between Islamic and conventional indices by running a unit-root test of the residual. In order to do that we regress each Islamic index on its benchmark using OLS regression, then we apply ADF test on residuals. Results (Table 2) show that the null hypothesis of unit-root test is rejected at $10 \%$ confidence interval for pairs of indices from FTSE and 
MSCI families, (FSAWRD and FAWRLD on one side, and MSACWS and MSWRLD on the other side). Indeed, residuals are stationary at level $\mathrm{I}(0)$. The presence of cointegration for two indices illustrates the existence of a longrun relationship between Islamic and conventional indices and thus there exists less diversification opportunities. It also implies that each index contains information for the prediction of the other index. Moreover, this evidence of cointegration has implications for portfolio diversification by the investors. The possibility of abnormal gain, in the long term, through portfolio diversification is limited among cointegrated indices.

Our results are in line with the findings of the previous studies using Dow Jones Islamic indices. Indeed, Guyot (2011) as well as Kok et al. (2009) found that these indices are cointegrated with their conventional counterparts, which means that no diversification opportunities exist in the long-run. As for the FTSE Islamic index, Girard and Hassan (2008) find that indices from this family are cointegrated with their benchmarks; this is in line with our results. However, our findings contrast with those of Kok et al. (2009) which conclude to the absence of cointegration and therefore, the existence of diversification opportunities among this index family. For the other families of Islamic indices (MSCI, S\&P), their cointegration with their corresponding benchmarks has not been studied before in the literature. As our article explores this issue for the first time, there is no reference in the literature to compare with.

Table 2: Cointegration Tests between Islamic and Conventional Indices

\begin{tabular}{|c|c|c|c|c|c|c|c|}
\hline \multirow{2}{*}{$\begin{array}{c}\text { Index } \\
\text { Families }\end{array}$} & \multirow{2}{*}{$\begin{array}{l}\text { Islamic and } \\
\text { Conventional } \\
\text { Indices }\end{array}$} & \multicolumn{2}{|c|}{$\begin{array}{c}\text { Stationarity of Series at } \\
\text { Level }\end{array}$} & \multicolumn{2}{|c|}{$\begin{array}{c}\text { Stationarity of Series at } 1^{\text {st }} \\
\text { Difference }\end{array}$} & \multicolumn{2}{|c|}{$\begin{array}{c}\text { Stationarity of the Residual } \\
\text { of Long-Run Relation }\end{array}$} \\
\hline & & ADF Test & Stationarity & ADF Test & Stationarity & ADF Test & Cointegration \\
\hline \multirow{2}{*}{$\begin{array}{l}\text { Dow } \\
\text { Jones }\end{array}$} & DJIMKT & $\begin{array}{l}-1.3827 \\
(0.5923)\end{array}$ & No & $\begin{array}{c}-41.01 * * * \\
(0.0000)\end{array}$ & Yes & \multirow{2}{*}{$\begin{array}{c}-1.524 \\
(0.1196)\end{array}$} & \multirow{2}{*}{ No } \\
\hline & W1DOW & $\begin{array}{l}-1.3122 \\
(0.6260)\end{array}$ & No & $\begin{array}{c}-40.04 * * * \\
(0.0000)\end{array}$ & Yes & & \\
\hline \multirow{2}{*}{ FTSE } & FSAWRD & $\begin{array}{l}-1.6317 \\
(0.4658)\end{array}$ & No & $\begin{array}{c}-21.629 * * * \\
(0.0000)\end{array}$ & Yes & \multirow{2}{*}{$\begin{array}{l}-3.295 * \\
(0.0676)\end{array}$} & \multirow{2}{*}{ Yes } \\
\hline & FAWRLD & $\begin{array}{l}-1.9747 \\
(0.2982)\end{array}$ & No & $\begin{array}{c}-31.49 * * * \\
(0.00)\end{array}$ & Yes & & \\
\hline \multirow{2}{*}{$\mathrm{S} \& \mathrm{P}$} & SP500S & $\begin{array}{l}-1.0393 \\
(0.7409) \\
\end{array}$ & No & $\begin{array}{c}-27.52 * * * \\
(0.0000) \\
\end{array}$ & Yes & \multirow{2}{*}{$\begin{array}{c}-2.594 \\
(0.2829)\end{array}$} & \multirow{2}{*}{ No } \\
\hline & SP500 & $\begin{array}{l}-1.1950 \\
(0.6786)\end{array}$ & No & $\begin{array}{c}-27.03 * * * \\
(0.0000)\end{array}$ & Yes & & \\
\hline \multirow{2}{*}{ MSCI } & MSACWS & $\begin{array}{l}-1.6633 \\
(0.4496) \\
\end{array}$ & No & $\begin{array}{c}-21.97 * * * \\
(0.0000) \\
\end{array}$ & Yes & \multirow{2}{*}{$\begin{array}{c}-1.677 * \\
(0.0885)\end{array}$} & \multirow{2}{*}{ Yes } \\
\hline & MSWRLD & $\begin{array}{l}-2.1566 \\
(0.2227)\end{array}$ & No & $\begin{array}{c}-21.98 * * * \\
(0.0000)\end{array}$ & Yes & & \\
\hline
\end{tabular}

Notes: ${ }^{*}, * *, * * *$ are significant levels at $10 \%, 5 \%, 1 \%$ respectively. $p$-values are shown in parentheses.

The previous cointegration analysis shows the long-run relationship between pairs of Islamic and conventional indices. In order to describe the short-run dynamics, the error correction model (ECM) is estimated for the cointegrated indices, namely FTSE and MSCI. Results from Table 3 reveal that the adjustment coefficient produced the expected sign (negative) and statistical significance for both pairs of cointegrated indices, at $10 \%$ and $1 \%$ level respectively for FTSE and MSCI. In fact, a mean-reversion process is observed since the error-correction coefficients are negative and significantly different from zero. For the Islamic index of MSCI, the coefficient is -0.1154 (significant at $1 \%$ ), but the speed of adjustment is slow for Islamic index of FTSE since the coefficient is -0.0249 (significant at $10 \%$ ). Also, we observe that the short-run dynamics of Islamic indices series of FTSE and MSCI, and their behavior regarding their past values are quite similar. Hence, their returns in the period " $\mathrm{t}$ " depend:

- Positively and significantly on their returns during the period "t-1"

- Positively and significantly on their benchmark returns during the period " $\mathrm{t}$ "

- Negatively and significantly on their benchmark returns during the period "t-1" 
Table 3: ECM Estimated for Indices of FTSE and MSCI Pairs of Indices

\begin{tabular}{|l|c|r|c|}
\hline \multicolumn{1}{|c|}{ Variable } & \multicolumn{1}{c|}{ Coefficient } & p value \\
\hline Dependant Variable: FSAWRD & $-0.0249^{*}$ & 0.0135 & 0.0660 \\
\hline RESIDUAL(-1) & $-0.3951^{* * *}$ & 0.0123 & 0.0000 \\
FAWRLD(-1) & $1.0081^{* * *}$ & 0.0125 & 0.0000 \\
FSAWRD(-1) & $0.3906 * * *$ & 0.0096 & 0.0000 \\
FAWRLD & $-0.1154^{* * *}$ & 0.0313 & 0.0002 \\
\hline Dependant Variable: MSACWS & $-0.8792^{* * *}$ & 0.0077 & 0.0000 \\
RESIDUAL(-1) & $0.9930^{* * *}$ & 0.0037 & 0.0000 \\
MSWRLD(-1) & $0.8855^{* * *}$ & 0.0072 & 0.0000 \\
MSACWS(-1) & &
\end{tabular}

Notes: $*, * *, * * *$ are significant levels at $10 \%, 5 \%, 1 \%$.

\subsection{Efficiency}

We perform the Lo and Mackinlay (1988) variance ratio tests for homoscedastic and heteroscedastic random walk in order to evaluate the efficiency of Islamic and conventional indices of our sample. The tests are computed for sampling intervals of 2, 5, 10, and 30 days. Results are shown in the following table:

Table 4: Variance Ratios of Islamic Indices and Their Benchmarks. $k=\{2,5,10,30\}$

\begin{tabular}{|c|c|c|c|c|c|c|}
\hline & & \multicolumn{2}{|c|}{ Assuming Homoscedasticity } & \multicolumn{2}{|c|}{ Heteroscedasticity-Robust } \\
\hline & $\mathbf{K}$ & $\mathbf{V R}(\mathbf{k})$ & $\mathbf{Z}(\mathbf{k})$ & p-value & $\mathbf{Z} *(\mathbf{k})$ & p-value \\
\hline \multirow{4}{*}{ DJIMKT } & $\mathrm{k}=2$ & 1.114470 & $6.4419 * * *$ & 0.0000 & $6.4419 * * *$ & 0.0000 \\
\hline & $\mathrm{k}=5$ & 1.121161 & $3.4316^{* * *}$ & 0.0006 & $3.1122 * * *$ & 0.0019 \\
\hline & $\mathrm{k}=10$ & 1.080615 & $1.7241 *$ & 0.0847 & 1.3436 & 0.1791 \\
\hline & $\mathrm{k}=30$ & 1.165290 & 1.231511 & 0.2181 & 1.5085 & 0.1314 \\
\hline \multirow{4}{*}{ W1 DoW } & $\mathrm{k}=2$ & 1.102305 & $5.7573 * * *$ & 0.0000 & $3.2822 * * *$ & 0.0010 \\
\hline & $\mathrm{k}=5$ & 1.116338 & $2.9883 * * *$ & 0.0028 & $1.7057 *$ & 0.0881 \\
\hline & $\mathrm{k}=10$ & 1.079467 & 1.3245 & 0.1853 & 0.7606 & 0.4468 \\
\hline & $\mathrm{k}=30$ & 1.178370 & 1.6279 & 0.1035 & 0.9462 & 0.3440 \\
\hline \multirow{4}{*}{ FSAWRD } & $\mathrm{k}=2$ & 1.122184 & $-1.8424 *$ & 0.0654 & $3.6204 * * *$ & 0.0003 \\
\hline & $\mathrm{k}=5$ & 1.121655 & $-2.2100 * *$ & 0.0271 & $1.6453^{*}$ & 0.0999 \\
\hline & $\mathrm{k}=10$ & 1.162923 & -1.6335 & 0.1023 & 1.4298 & 0.1528 \\
\hline & $\mathrm{k}=30$ & 1.329507 & -0.8995 & 0.3684 & 1.5834 & 0.1133 \\
\hline \multirow{4}{*}{ FAWRLD } & $\mathrm{k}=2$ & 0.937821 & $-1.8424^{*}$ & 0.0654 & -1.4155 & 0.1569 \\
\hline & $\mathrm{k}=5$ & 0.836592 & $-2.2100 * *$ & 0.0271 & -1.6010 & 0.1094 \\
\hline & $\mathrm{k}=10$ & 0.813857 & -1.6335 & 0.1023 & -1.1400 & 0.2543 \\
\hline & $\mathrm{k}=30$ & 0.812804 & -0.8995 & 0.3684 & -0.6348 & 0.5255 \\
\hline \multirow{4}{*}{ SP500S } & $\mathrm{k}=2$ & 0.859612 & $-4.5556 * * *$ & 0.0000 & $-3.0981 * * *$ & 0.0019 \\
\hline & $\mathrm{k}=5$ & 0.726870 & $-4.0454 * * *$ & 0.0001 & $-2.4508 * *$ & 0.0143 \\
\hline & $\mathrm{k}=10$ & 0.693203 & $-2.9485 * * *$ & 0.0032 & $-1.7426^{*}$ & 0.0814 \\
\hline & $\mathrm{k}=30$ & 0.740741 & -1.3643 & 0.1725 & -0.8092 & 0.4184 \\
\hline \multirow{4}{*}{ SP500 } & $\mathrm{k}=2$ & 0.863865 & $-4.4175 * * *$ & 0.0000 & $-3.1955 * * *$ & 0.0014 \\
\hline & $\mathrm{k}=5$ & 0.728969 & $-4.0143 * * *$ & 0.0001 & $-2.6406 * * *$ & 0.0083 \\
\hline & $\mathrm{k}=10$ & 0.673123 & $-3.1415 * * *$ & 0.0017 & $-2.0012 * *$ & 0.0454 \\
\hline & $\mathrm{k}=30$ & 0.731569 & -1.412631 & 0.1578 & -0.8845 & 0.3764 \\
\hline \multirow{4}{*}{ MSACWS } & $\mathrm{k}=2$ & 1.090752 & $2.6161 * * *$ & 0.0089 & $1.7789 *$ & 0.0752 \\
\hline & $\mathrm{k}=5$ & 1.051732 & 0.6806 & 0.4961 & 0.4126 & 0.6798 \\
\hline & $\mathrm{k}=10$ & 1.072286 & 0.6171 & 0.5371 & 0.3609 & 0.7181 \\
\hline & $\mathrm{k}=30$ & 1.146167 & 0.6833 & 0.4944 & 0.3998 & 0.6893 \\
\hline \multirow{4}{*}{ MSWRLD } & $\mathrm{k}=2$ & 1.079480 & $2.2911 * *$ & 0.0220 & 1.5842 & 0.1131 \\
\hline & $\mathrm{k}=5$ & 1.020857 & 0.2744 & 0.7838 & 0.1747 & 0.8613 \\
\hline & $\mathrm{k}=10$ & 1.010788 & 0.0921 & 0.9266 & 0.0567 & 0.9548 \\
\hline & $\mathrm{k}=30$ & 1.104986 & 0.4908 & 0.6236 & 0.2996 & 0.7645 \\
\hline
\end{tabular}

Notes: $*, * *, * * *$ are significant levels at $10 \%, 5 \%, 1 \%$ respectively. 
Table 4 reveals that when assuming homoscedasticity, the variance ratio test rejects the null hypothesis of random walk $\left(\mathrm{VR}_{\mathrm{k}}=1\right)$ for all the pairs of Islamic and conventional indices. We could deduce that all indices are inefficient since all the test statistics $\mathrm{Z}(\mathrm{k})$ are greater than critical values for $\mathrm{k}=2$. Also when we compare the efficiency level among indices we see that Islamic and conventional indices of MSCI and FTSE are less inefficient. The VR test also indicates the presence of positive serial correlation, since $\mathrm{VR}_{\mathrm{k}}>1$ for some indices returns across the sampling intervals. For this reason, we report also the test statistics adjusted for the violation of homoscedasticity.

With heteroscedasticity-robust tests $Z^{*}(\mathrm{k})$, the null hypothesis of random walk is not rejected for two conventional indices. They are characterized by $\mathrm{VR}_{\mathrm{k}}=1$ and confirm our previous findings that they are less inefficient and they tend towards efficiency. To check the robustness of our tests, we recalculate the variance ratios for sampling intervals of $2,4,8$, and 16 days. Table 5 confirms the previous results and provides additional information regarding the comparison of MSCI and FTSE indices families. Indeed, Z*(k) statistic shows that the null hypothesis of random walk hypothesis is rejected for the index FAWRLD for $\mathrm{k}=4$ at $5 \%$ significant level. So the index that gives the best level of weak-form efficiency is MSWRLD, the conventional index of MSCI.

Table 5: Variance Ratios of Islamic Indices and Their Benchmarks. $k=\{2,4,8,16\}$

\begin{tabular}{|c|c|c|c|c|c|c|}
\hline & \multirow[b]{2}{*}{$\mathbf{K}$} & \multirow[b]{2}{*}{ Var.Ratio } & \multicolumn{2}{|c|}{ Assuming Homoscedasticity } & \multicolumn{2}{|c|}{ Heteroscedasticity-Robust } \\
\hline & & & $\mathbf{Z}(\mathbf{k})$ & p value & $\mathbf{Z} *(\mathbf{k})$ & p value \\
\hline \multirow{4}{*}{ DJIMKT } & $\mathrm{k}=2$ & 1.114470 & $6.4419 * * *$ & 0.0000 & $3.8381 * * *$ & 0.0001 \\
\hline & $\mathrm{k}=4$ & 1.114081 & $3.4316 * * *$ & 0.0006 & $2.0379 * *$ & 0.0416 \\
\hline & $\mathrm{k}=8$ & 1.090623 & $1.7241 *$ & 0.0847 & 1.0366 & 0.2999 \\
\hline & $\mathrm{k}=16$ & 1.096324 & 1.2315 & 0.2181 & 0.7501 & 0.4531 \\
\hline \multirow{4}{*}{ W1 DOW } & $\mathrm{k}=2$ & 1.102305 & $5.7573 * * *$ & 0.0000 & $3.2822 * * *$ & 0.0010 \\
\hline & $\mathrm{k}=4$ & 1.104916 & $3.1559 * * *$ & 0.0016 & $1.7869 *$ & 0.0739 \\
\hline & $\mathrm{k}=8$ & 1.088143 & $1.6769 *$ & 0.0936 & 0.9638 & 0.3351 \\
\hline & $\mathrm{k}=16$ & 1.097322 & 1.2442 & 0.2134 & 0.7136 & 0.4755 \\
\hline \multirow{4}{*}{ FSAWRD } & $\mathrm{k}=2$ & 1.122184 & $3.6204 * * *$ & 0.0003 & $2.8354 * * *$ & 0.0046 \\
\hline & $\mathrm{k}=4$ & 1.107741 & $1.7064 *$ & 0.0879 & 1.1848 & 0.2361 \\
\hline & $\mathrm{k}=8$ & 1.154951 & 1.5521 & 0.1206 & 1.0171 & 0.3091 \\
\hline & $\mathrm{k}=16$ & 1.203315 & 1.3686 & 0.1711 & 0.8663 & 0.3863 \\
\hline \multirow{4}{*}{ FAWRLD } & $\mathrm{k}=2$ & 0.937821 & $-1.8424 *$ & 0.0654 & -1.4155 & 0.1569 \\
\hline & $\mathrm{k}=4$ & 0.829796 & $-2.6957 * * *$ & 0.0070 & $-1.9848 * *$ & 0.0472 \\
\hline & $\mathrm{k}=8$ & 0.811539 & $-1.8878^{*}$ & 0.0590 & -1.3249 & 0.1852 \\
\hline & $\mathrm{k}=16$ & 0.810763 & -1.2739 & 0.2027 & -0.8877 & 0.3747 \\
\hline \multirow{4}{*}{ SP500S } & $\mathrm{k}=2$ & 0.859612 & $-4.5556 * * *$ & 0.0000 & $-3.0981 * * *$ & 0.0019 \\
\hline & $\mathrm{k}=4$ & 0.742296 & $-4.4699 * * *$ & 0.0000 & $-2.7352 * * *$ & 0.0062 \\
\hline & $\mathrm{k}=8$ & 0.698656 & $-3.3057 * * *$ & 0.0009 & $-1.9657 * *$ & 0.0493 \\
\hline & $\mathrm{k}=16$ & 0.721554 & $-2.0527 * *$ & 0.0401 & -1.2019 & 0.2294 \\
\hline \multirow{4}{*}{ SP500 } & $\mathrm{k}=2$ & 0.863865 & $-4.4175 * * *$ & 0.0000 & $-3.1955 * * *$ & 0.0014 \\
\hline & $\mathrm{k}=4$ & 0.749718 & $-4.3412 * * *$ & 0.0000 & $-2.8808 * * *$ & 0.0040 \\
\hline & $\mathrm{k}=8$ & 0.684436 & $-3.4617 * * *$ & 0.0005 & -2.2289 & 0.0258 \\
\hline & $\mathrm{k}=16$ & 0.691239 & $-2.2762 * *$ & 0.0228 & -1.4221 & 0.1550 \\
\hline \multirow{4}{*}{ MSACWS } & $\mathrm{k}=2$ & 1.090752 & $2.6161 * * *$ & 0.0089 & $2.6161 * * *$ & 0.0089 \\
\hline & $\mathrm{k}=4$ & 1.035804 & 0.5517 & 0.5812 & 0.5517 & 0.5812 \\
\hline & $\mathrm{k}=8$ & 1.063637 & 0.6201 & 0.5351 & 0.6201 & 0.5351 \\
\hline & $\mathrm{k}=16$ & 1.085277 & 0.5584 & 0.5765 & 0.5584 & 0.5765 \\
\hline \multirow{4}{*}{ MSWRLD } & $\mathrm{k}=2$ & 1.079480 & $2.2911 * *$ & 0.0220 & 1.5842 & 0.1131 \\
\hline & $\mathrm{k}=4$ & 1.015366 & 0.2367 & 0.8128 & 0.1517 & 0.8794 \\
\hline & $\mathrm{k}=8$ & 1.008451 & 0.0823 & 0.9344 & 0.0512 & 0.9591 \\
\hline & $\mathrm{k}=16$ & 1.017638 & 0.1155 & 0.9080 & 0.0701 & 0.9441 \\
\hline
\end{tabular}

Notes: ${ }^{*}, * *, * * *$ are significant levels at $10 \%, 5 \%, 1 \%$ respectively.

Globally, our findings are in line with those of Guyot (2011) who finds that Islamic indices from the Dow Jones family present the same level of efficiency than conventional indices. But, our results contrast with those of Hassan (2001) when he finds that the Dow Jones Islamic index is more efficient than the conventional counterpart. 
One explanation of this divergence is that the study of Hassan (2001) included some back-tested data ${ }^{\dagger}$ and therefore, some caution is in order when discussing the findings as noted by Kurtz (2005). For the other families of Islamic indices (FTSE, MSCI, S\&P), they have not been studied before, so our article explores them for the first time, there is no reference in the literature to compare with.

\section{CONCLUSION AND POLICY RECOMMENDATION}

Islamic indices were launched to open the opportunities for investment in equity market by the investors according to their ethical commitment. This paper attempts to answer the question whether these indices offer an opportunity for portfolio diversification or not and whether they have the same efficiency level as their conventional counterparts or not. This paper, in order to answer these questions, analyzes four pairs of global Islamic and conventional indices covering the most important index families (Dow Jones, FTSE, Standard \& Poor's, and Morgan Stanley). Our study contributes to the current literature by addressing two main shortages. Firstly, we study the potential for diversification among pairs of indices as computed by globally reliable indices' providers. Secondly, we explore the area of the efficiency level of Islamic indices in relation with their conventional benchmarks. Two Islamic indices families included in our sample have not been studied before in the literature because of the short histories and some methodological difficulties linked to the size and the industry-weighting differences among indices. Hence, we analyze, for the first time either the cointegration or the efficiency of Islamic indices provided by MSCI and Standard and Poor's.

On one hand, the study of the cointegration is conducted using Engle and Granger's (1987) two-step approach based on stationarity tests. Our results reveal the absence of cointegration among two index families (Dow Jones and Standard \& Poor's). That means that diversification opportunities exist for the mentioned indices. For the two remaining pairs of indices (FTSE and MSCI), we found that they are cointegrated, which implies that a theoretical relationship exists among the indices. Presence of cointegration indicates the absence of diversification opportunities in the concerned indices. On the other hand, the efficiency analysis is carried out using the variance ratio tests of random walk hypothesis (Lo \& Mackinlay, 1988). Under the null hypothesis, price movement should show no path dependency. Our findings show that both Islamic and conventional indices have the same tendencies and therefore the same level of (in)efficiency. The variance ratio tests reveal that the global indices of FTSE and MSCI are the less inefficient. Interestingly, where we identify an absence of co-integration and the higher efficiency (Dow Jones and S\&P), these are market-capitalization based Shariah screening requirements and on the other hand where there exists co-integration and less efficiency (FTSE and MSCI) these are asset-based Shariah screening requirements.

The policy implications of our results could be twofold. Firstly, the evidence of cointegration may have significant impact for portfolio diversification by the managers and investors. Indeed, the possibility of abnormal gain through portfolio diversification is limited in the long-run for cointegrated pairs of assets (stock indices). Islamic indices could be as attractive as conventional ones for the portfolio managers and the international investors, since both indices tend to move together and have similar long-run diversification benefits. Secondly, the evidence of efficiency would have substantial effect on investors seeking investment opportunities in order to maximize their risk-adjusted returns without compromising their beliefs. The fact is that Islamic and conventional indices do not follow random walk, which leads to deviation from market efficiency. Actually, if stock prices do not reflect immediately all available information, this informational inefficiency offers opportunities to well-informed investors at the expense of other investors. In order to enhance efficiency, financial authorities as well as Shariah boards could improve the transparency level, respectively for global conventional and Islamic equity indices.

In terms of academic research, it would be interesting to study more indices since our study is limited to global Islamic indices. Future works should go for in depth analysis to look into Islamic sub-indices of each Islamic index family.

${ }^{\dagger}$ From January 1996 to December 1998, that represents 3 years among the 5 years of the study (from January 1996 to December 2000). 


\section{AUTHOR INFORMATION}

Abdelbari El Khamlichi, LERSEM, ENCG, Chouaib Doukkali University, Morocco

Kabir Sarkar, Taylor's Business School, Taylor's University, Malaysia

Mohamed Arouri, EDHEC Business School, France

Frédéric Teulon, IPAG Business School, France. E-mail: f.teulon@ipag.fr (Corresponding author)

\section{REFERENCES}

1. Ahmad, Z., \& Ibrahim, H. (2002). A study of performance of the KLSE Syariah Index. Malaysian Management Journal, 6(1-2), 25-34.

2. Ahmad, A. (1997). Towards an Islamic financial market a study of Islamic banking and finance in Malaysia. (Research Paper No45). IRTI, Islamic Development Bank.

3. Albaity, M., \& Ahmad, R. (2008). Performance of Syariah and composite indices: Evidence from Bursa Malaysia. Journal of Accounting and Finance, 4(1), 23-43.

4. Alhabshi, S. O. (1994). Development of capital market under Islamic principles. Conference on Managing \& Implementing Interest-Free Banking, January 25-26, Kuala Lumpur, Malaysia.

5. Annuar, M. N., Shamsher, M., \& Ngu, M. H. (1997). Selectivity and timing: Evidence from the performance of Malaysian unit trusts. Pertanika Journal of Social Science and Humanities, 5(1), 45-57.

6. Anwar, M. (1995). An Islamic perspective on capital markets and "Islamic" securities in Malaysia. The Pakistan Development Review, 4(34), 865-878.

7. Arouri, M. E. H., Ben Ameur, H., Jawadi, F., Jawadi, N., \& Louhichi, W. (2013). Are Islamic finance innovations enough for investors to escape from a financial downturn? Further evidence from portfolio simulations. Applied Economics, 35(24), 3412-3420.

8. Binmahfouz, S., \& Hassan, K. (2012). A comparative study between the investment characteristics of Islamic and socially responsible investment portfolios: Evidence from FTSE indices family. International Conference on Islamic Capital Markets, 19-20 June, Jakarta, Indonesia.

9. Dabbeeru, R. N. (2006). Performance analysis of mutual funds in Saudi Arabia. SSRN eLibrary. Retrieved from http://ssrn.com/paper $=921523$

10. Derigs, U., \& Marzban, S. (2008). Review and analysis of current Shariah-compliant equity screening practices. International Journal of Islamic and Middle Eastern Finance and Management, 1(4), 285-303.

11. Derigs, U., \& Marzban, S. (2009). New strategies and a new paradigm for Shariah-compliant portfolio optimization. Journal of Banking and Finance, 33(6), 1166-1176.

12. Ebrahim, M. S., \& Safadi, A. (1995). Behavioral norms in the doctrine of Islamic economics: A comment. Journal of Economic Behavior and Organization, 27, 151-157.

13. El-Gamal, M. A. (2002). An economic explanation of the prohibition of Gharar in classical Islamic jurisprudence. In M. Iqbal (ed.), Islamic banking and finance: Current developments in theory and practice (pp. 49-88). UK: Islamic Foundation Leicester.

14. El-Gamal, M. A. (2006). Islamic finance: Law, economics and practice. Cambridge University Press.

15. Elgari, M. A. (1993). Towards an Islamic stock market. Islamic Economic Studies, 1(1), 1-20.

16. Engle, R. F., \& Granger, C. W. J. (1987). Cointegration and error correction: Representation, estimation and testing. Econometrica, 55(2), 251-276.

17. Fama, E. F. (1965). Random walks in stock market prices. Financial Analysts Journal, 21(5), 55-59.

18. Fowler, S. J., \& Hope, C. (2007). A critical review of sustainable business indices and their impact. Journal of Business Ethics, 76(3), 243-252.

19. Ghoul, W., \& Karam, P. (2007). MRI and SRI mutual funds: A comparison of Christian, Islamic (morally responsible investing), and socially responsible investing (SRI) mutual funds. Journal of Investing, 16(2), 96.

20. Gilmore, C. G., \& McManus, G. (2003). Random-walk and efficiency tests of central European equity markets. Managerial Finance, 29, 42-52.

21. Girard, E., \& Hassan, M. K. (2008). Is there a cost to faith-based investing: Evidence from FTSE Islamic indices. The Journal of Investing, 17(4), 112-121. 
22. Guidi, F., \& Gupta, R. (2011). Are ASEAN stock market efficient? Evidence from univariate and multivariate variance ratio tests. (Discussion Papers in Finance, $\mathrm{n}^{\circ} 13$ ). Griffith University.

23. Guyot, A. (2011). Efficiency and dynamics of Islamic investment: Evidence of geopolitical effects on Dow Jones Islamic market indexes. Emerging Markets Finance and Trade, 47(6), 24-45.

24. Hakim, S., \& Rashidian, M. (2004). How costly is investors' compliance to Sharia? Proceedings of the $11^{\text {th }}$ Economic Research Forum Annual Conference. Sharjah, UAE.

25. Hakim, S., \& Rashidian, M. (2002). Risk \& return of Islamic stock market indexes. $9^{\text {th }}$ Economic Research Forum Annual Meeting, 26-28 October, Sharjah UAE.

26. Hassan, M. K. (2001). Risk, return and volatility of faith-based investing: The case of DJIM. Boston, Massachusetts.

27. Hoque, H. A. A. B., Kim, J. H., \& Pyun, C. S. (2007). A comparison of variance ratio tests of random walk: A case of Asian emerging stock markets. International Review of Economics \& Finance, 16(4), 488-502.

28. Hussein, K. (2004). Ethical investment: Empirical evidence from FTSE Islamic index. Islamic Economic Studies, 12(1), 21-40.

29. Iqbal, M. (2002). Islamic banking and finance: Current developments in theory and practice. Leicester, UK: Islamic Foundation.

30. Jobst, A. A. (2007). The economics of Islamic finance and securitization. Journal of Structured Finance, $13(1), 6-27$.

31. Kuran, T. (1983). Behavioral norms in the Islamic doctrine of economics: A critique. Journal of Economic Behavior and Organization, 4, 353-379.

32. Khan, F. (2010). How 'Islamic' is Islamic banking? Journal of Economic Behavior \& Organization, 76, 805820.

33. Kok, S., Giorgioni, G., \& Laws, J. (2009). Performance of Shariah-compliant indices in London and NY stock markets and their potential for diversification. International Journal of Monetary Economics and Finance, 2(3), 398-408.

34. Kurtz, L. (2005). Answers to four questions. Journal of Investing, Fall, 125-139.

35. Lo, A. W., \& MacKinlay, A. C. (1988). Stock market prices do not follow random walks: Evidence from a simple specification test. Review of Financial Studies, 41-66.

36. Malkiel, B. G. (2003). The efficient market hypothesis and its critics. Journal of Economic Perspectives, 17(1), 59-82.

37. Miglietta, F., \& Forte, G. (2007). Islamic mutual funds as faith-based funds in a socially responsible context. Milan: Luigi Bocconi University.

38. Naughton, S., \& Naughton, T. (2000). Religion, ethics and stock trading: The case of an Islamic equities market. Journal of Business Ethics, 23(2), 145-159.

39. Nishat, M. (2004). Experience of equity-based Islamic shares in Pakistan. Pakistan Development Review, 41(2), 583-602.

40. Obaidullah, M. (2001). Ethics and efficiency in Islamic Stock Markets. International Journal of Islamic Financial Services, 3(2), 1-10.

41. Smith, G., \& Ryoo, H. J. (2003). Variance ratio tests of the random walk hypothesis for European emerging stock markets. The European Journal of Finance, 9(3), 290-300.

42. Tilva, R., \& Tuli, J. (2002). Islamic Banking: A new era of financing. Google Scholar. Retrieved from http://www.globalwebpost.com/farooqm/study_res/i_econ_fin/tilva_tuli_ibanking.pdf

43. Wright, J. H. (2000). Alternative variance-ratio tests using ranks and signs. Journal of Business \& Economic Statistics, 18(1), 1-9.

44. Yaquby, N. (2000). Participation and trading in equities of companies whose main business is primarily lawful but fraught with some prohibited transactions. Fourth Harvard Islamic Finance Forum. September 30-1st October.

45. Yusof, R. M., \& Majid, M. S. A. (2007). Stock market volatility transmission in Malaysia: Islamic versus conventional stock market. Journal Islamic Economics, 20(2), 17-35. 
Appendix 1: Most Important Islamic Indices

\begin{tabular}{|c|c|c|c|}
\hline Index & Launch & Provider & $\begin{array}{ll}\text { Characteristics } \\
\end{array}$ \\
\hline $\begin{array}{l}\text { Dow Jones } \\
\text { Islamic Market } \\
\text { Index (DJIMI) }\end{array}$ & February 1999 & Dow Jones & $\begin{array}{l}\text { - } \quad \text { Geographical coverage: } 66 \text { countries } \\
\text { - } \quad \text { Sectorial allocation } \\
\text { - } \quad \text { Shariah board: } 5 \text { independant Scholars } \\
\text { Trimestrial revision }\end{array}$ \\
\hline $\begin{array}{l}\text { Global Islamic } \\
\text { Index Series } \\
\text { (GIIS) }\end{array}$ & October 1999 & FTSE Group & $\begin{array}{l}\text { Include } 3 \text { index series: } \\
\text { - } \quad \text { FTSE SGX Shariah Index Series (with Singapore Exchage) } \\
\text { - } \quad \text { FTSE DIFX Shariah Index Series (with Nasdaq Dubai) } \\
\text { - } \quad \text { FTSE Bursa Malaysia Index Series (With Bursa Malaysia) }\end{array}$ \\
\hline $\begin{array}{l}\text { MSCI Global } \\
\text { Islamic Indices }\end{array}$ & March 2007 & $\begin{array}{l}\text { Morgan } \\
\text { Stanley }\end{array}$ & $\begin{array}{l}\text { - } \quad \text { Geographical coverage: } 70 \text { countries } \\
\text { - } \quad \text { Sectorial allocation } \\
\text { - } \quad \text { Trimestriah board: Dar al Istitmar ( } 5 \text { scholars }) \\
\text { Trision }\end{array}$ \\
\hline $\begin{array}{l}\text { S\&P Shariah } \\
\text { Index Series }\end{array}$ & December2006 & $\begin{array}{l}\text { Standard and } \\
\text { Poor's }\end{array}$ & $\begin{array}{l}\text { - } \quad \text { Geographical coverage: } 70 \text { countries } \\
\text { - } \quad \text { Sectorial allocation } \\
\text { - } \quad \text { Shariah board: Rating Intelligence Partners } \\
\quad \text { Trimestrial revision }\end{array}$ \\
\hline $\begin{array}{l}\text { Stoxx Europe } \\
\text { Islamic indices }\end{array}$ & February 2011 & Stoxx & $\begin{array}{l}\text { - } \quad \text { Geographical coverage: Europe and Euro Zone } \\
\text { - } \quad \text { Sectorial allocation } \\
\text { - } \quad \text { Trimestrial revision }\end{array}$ \\
\hline
\end{tabular}




\section{Appendix 2: Qualitative and Quantitative Screens used by Shariah Board of Dow Jones}

\section{Industry Screens}

According to Dow Jones Islamic Market Index (DJIMI) standards, if the company has business activities in any one of the following sectors defined by the Industry Classification Benchmark (ICB), it is considered inappropriate for Islamic investment purposes and is excluded from the index:

\begin{tabular}{|c|}
\hline $\begin{array}{l}2717 \text { Defense } \\
3535 \text { Distillers \& Vintners } \\
3577 \text { Food Products } \\
3745 \text { Recreational Products } \\
3785 \text { Tobacco } \\
5337 \text { Food Retailers \& Wholesalers } \\
5553 \text { Broadcasting \& Entertainment } \\
5555 \text { Media Agencies } \\
5752 \text { Gambling } \\
5753 \text { Hotels } \\
\text { 5755 Recreational Services } \\
\text { 5757 Restaurants \& Bars } \\
\text { 8355 Banks } \\
\text { 8532 Full Line Insurance } \\
\text { 8534 Insurance Brokers } \\
\text { 8536 Property \& Casualty Insurance } \\
\text { 8733 Real Estate Holding \& Development } \\
\text { 8773 Consumer Finance } \\
8775 \text { Specialty Finance } \\
8777 \text { Investment Services } \\
8779 \text { Mortgage Finance }\end{array}$ \\
\hline
\end{tabular}

\section{Financial Ratios Screens}

To be included in Dow Jones Islamic Market index, the financial ratios of firms are screened. Thus, all of the following should be less than $33 \%$ :

- $\quad$ Total debt divided by trailing 24-month average market capitalization

- $\quad$ The sum of a company's cash and interest-bearing securities divided by trailing 24 month average market capitalization

- $\quad$ Accounts receivables divided by trailing 24-month average market capitalization

Source: Dow Jones documentation: (http://www.djindexes.com/literature) 